\title{
Tribute, hope and reconciliation
}

\begin{tabular}{|c|c|}
\hline \multicolumn{2}{|c|}{$\begin{array}{l}\text { Authors: } \\
\text { Jürgen Moltmann } \\
\text { Olav F. Tveit } \\
\text { Klaus Nürnberger } \\
\text { Johan Buitendag }^{1}\end{array}$} \\
\hline \multicolumn{2}{|c|}{$\begin{array}{l}\text { Affiliations: } \\
{ }^{1} \text { Department of Dogmatics } \\
\text { and Christian Ethics, Faculty } \\
\text { of Theology, University of } \\
\text { Pretoria, South Africa }\end{array}$} \\
\hline \multicolumn{2}{|c|}{$\begin{array}{l}{ }^{2} \text { World Council of Churches, } \\
\text { Geneva, Switzerland }\end{array}$} \\
\hline \multicolumn{2}{|c|}{$\begin{array}{l}{ }^{3} \text { Emeritus Professor, University } \\
\text { of Tübingen, Germany }\end{array}$} \\
\hline \multicolumn{2}{|c|}{$\begin{array}{l}\text { Research Project Registration: } \\
\text { Project Leader: J. Buitendag } \\
\text { Project Number: } 02402343\end{array}$} \\
\hline \multicolumn{2}{|c|}{$\begin{array}{l}\text { Prof. Dr J. Moltmann's } \\
\text { contribution and the tribute } \\
\text { authored by Prof. Dr Klaus } \\
\text { Nürnberger resorts under the } \\
\text { research project, 'University, } \\
\text { Education and Theology', } \\
\text { directed by Prof. Dr Johan } \\
\text { Buitendag, Department of } \\
\text { Dogmatics and Christian Ethics, } \\
\text { and Dean, Faculty of Theology, } \\
\text { University of Pretoria. }\end{array}$} \\
\hline \multicolumn{2}{|c|}{$\begin{array}{l}\text { Corresponding author: } \\
\text { Johan Buitendag, } \\
\text { johan.buitendag@up.ac.za }\end{array}$} \\
\hline \multicolumn{2}{|c|}{$\begin{array}{l}\text { Received: } 28 \text { June } 2017 \\
\text { Accepted: } 18 \text { Aug. } 2017 \\
\text { Published: } 05 \text { Dec. } 2017\end{array}$} \\
\hline \multicolumn{2}{|c|}{$\begin{array}{l}\text { How to cite this article: } \\
\text { Moltmann, J., Tveit, O.F., } \\
\text { Nürnberger, K. \& Buitenda } \\
\text { J., 2017, 'Tribute, hope an } \\
\text { reconciliation', HTS } \\
\text { Teologiese Studies/ } \\
\text { Theological Studies 73(1), } \\
\text { a4724. https://doi.org/ } \\
\text { 10.4102/hts.v73i1.4724 }\end{array}$} \\
\hline \multicolumn{2}{|c|}{$\begin{array}{l}\text { Copyright: } \\
\text { (c) 2017. The Authors. } \\
\text { Licensee: AOSIS. This work } \\
\text { is licensed under the Creative } \\
\text { Commons Attribution License. }\end{array}$} \\
\hline \multicolumn{2}{|l|}{ Read online: } \\
\hline aftu & $\begin{array}{l}\text { Scan this QR } \\
\text { code with your } \\
\text { smart phone or } \\
\text { mobile device } \\
\text { to read online. }\end{array}$ \\
\hline
\end{tabular}

This article represents a trilogy of tribute to and by Jürgen Moltmann on 05 and 06 April 2017 during the centenary celebrations of the Faculty of Theology at the University of Pretoria and the conferment of an honorary doctorate to Moltmann. The first tribute to Prof. Moltmann is an address from the General Secretary, World Council of Churches, Geneva, Switzerland, Rev. Dr Olav Fykse Tveit. In this he honours Professor Moltmann's prophetic reflection on how theology can bring the living God we all believe in to the world today, so that human beings and the entire creation can experience the fullness of life that God promised to us all. The second tribute is authored by Klaus Nürnberger, in which he reflects on Moltmann's legacy for South Africans. The second part is Prof. Moltmann's acceptance speech the graduation ceremony on 06 April when he addressed the new graduandi and their families and friends at the Rembrandt Hall, University of Pretoria. He inspires the newly graduandi by saying: 'In the end - there is a beginning. Young men and women, let your hope arise. We have so much of sick and dying hope around us. There is resignation. There is the arrogance of the powerful, and there is the apathy of powerless. Drop arrogance and learn to listen to others. Get out of apathy and lift up your head and raise your voices. Break out of indifference and get involved. Life is so beautiful'. The last section echoes Moltmann's lifelong emphasis on the living power of hope and focuses on the power of forgiveness to mend broken relationships. This is not an easy task, and where it is up to humanity, utterly impossible to cross the divides the human condition can create. Moltmann focuses on how the reconciliation of Christ with humanity creates bridges for humanity to reconcile with one another. Reconciliation restores relationships and opens a 'gateway' to the future. In this way, Moltmann highlighted the theme of the centenary celebration of the Faculty of Theology of the University of Pretoria.

\section{'Word of congratulations by the World Council of Churches' - Olav F. Tveit}

Congratulations to Prof. Dr Jürgen Moltmann on being awarded an honorary doctorate by the University of Pretoria, 06 April 2017

Geneva, 31 March 2017

Spectabiles,

Prof. Jürgen Moltmann,

Prof. Johan Buitendag, Dean of the Theological Faculty, esteemed representatives of the University of Pretoria, Honourable leadership of the Dutch Reformed Church, and of other churches,

Dear brothers and sisters,

It is a great pleasure for me as the General Secretary of the World Council of Churches to greet you all in the name of the Triune God we all worship, on this special occasion of the awarding of an honorary doctorate to Prof. Dr Jürgen Moltmann by the University of Pretoria, as proposed by the Theological Faculty.

This festive occasion holds several layers of significance and brings together several churches, personages, academic institutions, and even different hemispheres of the same oikoumene, God's created world. On the one hand, the Theological Faculty in Pretoria celebrates this year its centenary with numerous academic, ecclesial, and ecumenical events, including the conference held today. Furthermore, the ordinary meetings of the Faith and Order Commission will be hosted by your Theological Faculty in June this year with the generous support of the Dutch Reformed Church and of other churches in South Africa; they will be integrated into this series of celebratory 
events. A centenary is not only a great occasion for celebration, remembrance and evaluation of the past but also for planning and envisaging the future. Part of celebrating, but also of planning and envisaging, is recognising and honouring persons who have made a substantial contribution and a real difference in terms of theological reflection, in reshaping the role of theology for today's world and for the future.

Professor Jürgen Moltmann is certainly one of the theologians of 21st century whose theological contribution mostly bears hearing, reflection and honouring. By awarding this doctorate to Professor Moltmann, your university joins an already-large group of academic institutions of various confessional backgrounds from all around the world who have awarded him with different academic titles. Because he is someone who experienced the horrors of the Second World War at a personal level, formulated the startling insights of the theology of hope and of political theology, has been deeply engaged in the ecumenical quest, and has influenced the religious life of the churches, the impact of his theology crosses confessional and international borders. But he is one of today's most influential systematic theologians because his unique ability to reframe and rethink classical theological topics in truly creative, profound and life-giving ways inspires theologians everywhere, not least in new contexts and in newly established churches, especially in the global South.

As WCC General Secretary, I personally value Professor Moltmann's ecumenical theology and vision. In January 2016, he visited the Ecumenical Centre in Geneva and launched his book, published by WCC Publications, entitled The Living God and the Fullness of Life. In his lecture, addressed to a large audience composed of staff from the WCC and other ecumenical institutions and of students from Bossey Ecumenical Institute and the University of Geneva, as in the book itself, Professor Moltmann developed a prophetic reflection on how theology can bring the living God we all believe in to the world today, so that human beings and the entire creation can experience the fullness of life that God promised to us all. We, as Christians living in the 21st century, are empowered in this mission by the example of early Christians, who were able to conquer the ancient world 'with [their] message about Christ: He is "the resurrection and the life"' (p. vii). Professor Moltmann's strong message to us was and is: if early Christianity was able to transform the ancient world, then today's Christianity contains the same potential for transformation of the contemporary world.

I am delighted that Professor Moltmann's theology and his ecumenical visions speak to your context and inspire theological reflection in your Faculty. By awarding Prof. Moltmann, a theologian from the global north, an honorary degree here in Pretoria, in an academic institution that serves peoples and churches in a particular context in the global South, you are embracing us all with a vision of unity that is meaningful for the entire oikoumene.

Congratulating the university for this initiative and Professor Moltmann for receiving it, I remain yours in our God and Saviour Jesus Christ.

\section{'The legacy of Jürgen Moltmann for us today' - Klaus Nürnberger}

Today we celebrated a great theologian. By doing so we identified ourselves with his basic motivation. But the Sunday atmosphere of celebration is meant to gather our energies for the hard work awaiting us on Monday. The genuine way to celebrate a great example is to take over his legacy and run with it. It is like a relay race. Once the baton is in your hand, the outcome of the race depends on you.

Let me share with you what this has meant for my own life here in South Africa. I encountered Moltmann's (2012) Theology of Hope, when my mentor, Karl Heinz Ratschow, conducted a seminar on the book in Marburg in the 1960s. At that time three schools dominated Systematic Theology in Germany: the confessional theology headed by Karl Barth, the existentialist theology headed by Rudolf Bultmann, and the Luther Renaissance to which Ratschow belonged.

Moltmann's Theology of Hope gushed over this entire scene like an avalanche. Dialectical Theology concentrated on the ontological 'being' of God in his revelation. Existentialist theology concentrated on gaining the personal authenticity of the believer. The Luther Renaissance reaffirmed its stance on law and grace after Karl Barth's devastating critique. Moltmann's book Theology of Hope exploded these narrow confines.

Why was that important? At the time society had become anxious and restless. The Cold War had become critically dangerous. Europe stood at the brink of a nuclear holocaust. The atrocities of the Vietnam War triggered the revolt of the youth in the United States. Decolonisation revealed the massive discrepancies of life chances between the First and the Third Worlds. The neo-Marxist sociology of the Frankfurt School excited the imagination of the younger generation. Ecological awareness was aroused through the dying of the forests, a highly emotional issue in Germany. A little book on The Limits to Growth (produced by the so-called Club of Rome, edited by D.H. Meadows et al. 1972; see Moltmann 2012:xi, 49,221 ) rattled the certainties of the capitalist status quo.

Moltmann's (2012) Theology of Hope was the theological version of Ernst Bloch's (1954/1955/1959) three-volume Das Prinzip Hoffnung. The new approach activated the constructive energies of the human being in the face of immense dangers and predicaments. Bloch was a neo-Marxist who claimed that Marxism was the legitimate heir of the messianic and apocalyptic thrust of the biblical tradition, a tradition that had lost its theological traction.

Moltmann put the untapped positive potentials of an unfolding socio-political history back onto the theological agenda. For my situation as a South African, that was exceptionally important. I had studied agricultural economics and had worked in the field of rural development planning in the impoverished black areas of South Africa. The problem 
of poverty, economic development and ecological devastation had become my overriding concern - more fundamental even than the impasses of the apartheid system.

I had understood that, if there was to be progress in this field, convictions had to change both among the powerful and among the powerless. However, confessional theology, existentialist theology, and the Lutheran two-kingdom doctrine gave me no theological handle to this problem.

Neo-Marxism presented the challenge to rethink our certainties. It opened my eyes to the phenomenon of ideology. Ideology distorts generally accepted convictions and ethical precepts to legitimate the pursuit of collective interests at the expense of others. When it comes to the push, interests almost always overpower convictions.

It is an insight that we still have to learn. It explains why black Lutherans in Namibia opted against the apartheid system, while white Lutherans supported it. It explains why the prophetic voice of the churches during the apartheid struggle evaporated when liberation had been achieved in Namibia and South Africa.

In the heated and painful debates, I discovered the importance of confrontation, not between people, but between the spiritual powers on which people and societies had based their lives. The gospel of Christ provided the canopy of unconditional mutual acceptance under which such confrontations could happen in brutish honesty without giving up on each other.

This approach proved its strength and viability within churches, ecumenical institutions and theological seminaries when the apartheid system began to be challenged by the new generation of black Christians, empowered by the movement of Liberation Theology and Black Theology that engulfed us in the 1970s.

Bloch's and Moltmann's emphasis on an anticipatory consciousness found expression in the concept of a 'real utopia'. A real utopia did not refer to an apocalyptic dream world but to the untapped potential of the existing world. A real utopia can materialise, although at present it seems highly unlikely. A number of real utopias actually materialised: the nuclear holocaust did not happen; the Cold War came to an end; Germany was reunified; apartheid made way for a democratic dispensation.

This vibrant debate came to a sudden end when the Soviet Union collapsed in 1989 and the apartheid era ended soon after. Activists became state officials or capitalist entrepreneurs. The churches withdrew into their cocoons. Personal authenticity and social-critical consciousness drowned in the postmodern swamp.

The liberal-capitalist system established itself as the only show in town - not only among the rich but also among the poor. The disillusionment of the disadvantaged and marginalised (in South Africa the vast majority) explodes into sporadic violence claiming the right to work, to housing, to social grants, to service delivery, to free education. The status and wealth of the powerful is not critiqued but envied and aspired. The election of Trump, a trillionaire, by those who feel economically left out in the United States is symptomatic!

In the meantime humanity moves in the direction of a massive catastrophe. Let me mention a few facets of the current trend: the population is growing in the poorest sections of the population while the economy stagnates; the productive potential of the elite undergoes a relentless growth; labour can no longer compete with the exploding powers of technology, leading to massive unemployment. In South Africa about half of the potential work force cannot be accommodated in the formal economy. Millions depend on social grants just to survive.

Staggering discrepancies in income and life chances open up. The GDP per capita of the United States is 150 times as large as that of the Democratic Republic of the Congo. Both in South Africa and in the United States the top 10\% command $75 \%$ of the income; the bottom $50 \%$ of the population gets less than $3 \%$.

The expectations of the poor are raised sky-high by exposure to the 'good life' on cell phones and television screens. The advertising and entertainment industries have successfully replaced contentment and responsibility with the quest for immediate profit and pleasure.

Now multiply a growing population with growing expectations, and again with growing needs for energy and natural resources, and you realise that this is turning into a tsunami flooding the natural world and endangering the very survival of the poor and powerless, which are the majority of the population.

The modem economy is powered by science, technology, globalised commercial pressures and the consumer culture. It has developed a dynamic of its own that moves on regardless of the actors involved. The crew of the Titanic is not aware that the ship is heading for the iceberg; those who know better cannot turn such a massive ship around before it crashes.

Has a theology of hope lost its credibility in view of socioeconomic dynamics, the insights of modern science and the erosion of certainties by postmodern deconstruction and pluralistic relativity? Has faith lost its traction? Has eschatological hope re-established its function as an escapist rather than a transformative spiritual motivation in the blossoming growth of new churches and spiritual movements worldwide?

Eschatology has become the most vulnerable and the most critically important issue for theology. Jürgen Moltmann insisted that the power of hope is greater than the power of 
indifference and the power of despair. That is the legacy he leaves us and with which we now have to run. It is not easy to translate it into realistic, interdisciplinary and professional terms. The point is, however, that those who put their hands to the plough cannot want to look back or enjoy their beer under a tree. Theology is not meant to be a picnic. Jürgen Moltmann has demonstrated this fact over decades and we are grateful for the outcome of his work.

\section{'In my end is my beginning' - Jürgen Moltmann}

Dear students and your families,

You are standing at the end of your studies, and the beginning of a new life is waiting upon you. The time of learning and thanks to God - of examinations is finished, and a free-life is expecting you. The life of security is gone, your life will become risky, but it will be your own adventure.

I remember: some 65 years ago, I experienced my first graduation, and I was restless like a trained horse longing for the racecourse. In this situation between the end and the beginning, it is good to stop for a second and to ask oneself: What life do I really want? Our lifetime does no longer consist of regular time flow but again and again of an end and a new beginning, as T.S. Eliot said: 'In the end is my beginning' - if there is a new beginning? About this confidence, that there is a new beginning, waiting for you, if you seek for it, I want to speak to you.

To see a new beginning is certainly the most exciting event we can experience in life. 'In every beginning there is a magic', wrote the poet Hermann Hesse, a 'magic' that can fascinate and inspire us. It is, I guess, the promise of freedom. 'In the beginning God created heavens and earth', and 'in the beginning' there is for us the broad place of freedom, inviting our own creativity. We correspond to the creator of the world, the great 'beginner' of life. Therefore to begin something, you are convinced to be meaningful, is as beautiful as the adventure of life.

Our task is to begin something new; God's task is to complete, to set right, and to heal what we humans - all too humanly - have begun. In this trust we can go over our limits: 'Think big'. In this hope we can leave behind our traditions and try to create something greater : 'Oopmaak van die hekke...'

In a beginning, our life becomes alive from within. It is so sad, not knowing, what to begin with one's own life, not knowing, what to make out of your own life. And if our beginnings fail and end in disappointments, we do not give up. If a child falls down, it doesn't matter: the child learns to stand up. It is like this our life long. You may be a hundred times disappointed by other or by yourself, don't give up! To begin something new, it is never too late. 'Dum spiro-spero' As long as I breathe, so long I hope!

Hope is a great power to leave to the old behind and to begin something new. 'Hope dies last' is a saying. But I am not sure, whether all our life expectations hold out to the end. I believe more in 'the rebirth to a living hope', because when I was of your age I have experienced this myself: When I was 18 and my life began, it ended all of a sudden: I became a soldier in the dying German army and in 1945 a 'Prisoner of War' for 3 years. I walked along the barbed wire and felt forsaken by God and all good spirits. Then I got a Bible into my hands and found in the psalms of lament words for my misery. The passion story of Christ spoke to me and I set my confidence in Christ and became certain he would take me into the resurrection and full life. My end became my beginning, a change I had not expected. What looked like a grim fate, when it began, turned into an undeserved rich blessing. I came into War Prisonship with a wounded soul, and when I left in 1948 my soul was healed. Ever since I am convinced: in every No is hidden a Yes of God. In every end there is hidden a new beginning.

The beginning of what? When we look upon God, we speak of the kingdom of God and God's righteousness. When we look upon us human beings and the earth, in which we live, we speak of the Fullness of life and its living beauty. When we hope for the kingdom and the fullness of life, we become wide awake and curious. We don't sleep in the routine of life and work. Life doesn't become a bore. 'Pray and watch', we read in the New Testament. We know prayer but to watch is new. It is directed towards the future. When we watch, we discern the 'signs and wonders' of the coming fullness of life and grasp the chances for the justice of the kingdom. We pray so to speak with 'open eyes'.

To hope is an exited expectation to grasp the fortunate chances for the fullness of life and the kingdom, for beauty and justice. There is no more exiting, than a life story lived in the expectations of God. What is the will of God with my life? What does God tell us through the events of the day? Our Forefathers and Foremothers listened and met their chances. There are always signs and wonders. Remember 1989 when a peaceful revolution of the people unified divided Germany and remember 1993 when Nelson Mandela and Willem de Klerk changed peacefully South Africa into a living democracy for all the people. Sometimes we have ears, but don't listen; eyes, but don't see. However, we can hear the inviting promise and see the lived promise: 'Lord, when have we seen you as emigrant, and as sick of aids, as hungry and thirsty?', we have to confess someday. The overlooked son of man is in our midst.

Whoever believes in the 'Living God' sees the world not only in the reality. The so-called realists do that and are always late. But the one who believes also sees the world in the possibilities. 'All things are possible to him who believes', because 'all things are possible with God'. All reality is realised possibility. Possibility comes first, reality afterwards. Therefore, the possibility stands higher as the reality. For a long time, historians told history, as if it is all destiny. But we see now, that the First World War, the 'European original catastrophe' must not have happened if there were other possibilities at hand. 
It is our task to discern the opportunities for peace and realise them. There is no fate or destiny in history, but only responsibility. Become possibility seekers, find the opportunities for life and refuse the opportunities of death. In a cockpit of an airplane I found the notice: 'Think ahead of the airplane'.

To be wakeful means not only to discover objective opportunities for the fullness of life but also to use one's imagination, in German: die Einbildungskraft zu gebrauchen, to invent new possibilities and to design new projects. For all our interests, we use our imagination to realise them if possible. Why not use our imagination for public affairs, for the kingdom and the justice of God for all and for the fullness of life and the living beauty? One must not be a prophet to do that.

In my younger years, I read Alan Paton's book Cry, My Beloved Country. My country Germany and your country South Africa are crying for justice and suffer pain from injustice. For years we have heard repeatedly and everywhere the charge that the social gap between rich and poor is widening. Democracy, however, demands not only freedom but also equality. The imbalance between freedom and equity has become lifethreatening, but the alternative to poverty is not property: The alternative to poverty and property is 'community'. By 'community' we mean here the visible solidarity, as well as the inner togetherness of society in social balance and social freedom. It is, after all, not a football game that unites a society, exciting as they are, it is social justice that creates lasting peace. This is M. Luther King's 'beloved community'.

In the end - there is a beginning. Young men and women, let your hope arise:

We have so much of sick and dying hope around us. There is resignation. There is the arrogance of the powerful, and there is the apathy of powerless. Drop Arrogance and learn to listen to others. Get out of apathy and lift up your head and raise your voices.

Break out of indifference and get involved. Life is so beautiful:

God bless you and your families.

God bless this university and teachers and students.

God bless South Africa, the 'beloved country'.

\section{'Reconciliation behind barbed wire' - Jürgen Moltmann Introduction}

The last section of the trilogy represents a public lecture delivered by Jürgen Moltmann on 05 April 2017 during the centenary celebrations of the Faculty of Theology at the University of Pretoria. It echoes Moltmann's lifelong emphasis on the living power of hope and focuses on the power of forgiveness to mend broken relationships. This is not an easy task, and where it is up to humanity, utterly impossible to cross the divides the human condition can create. Moltmann focuses on how the reconciliation of Christ with humanity creates bridges for humanity to reconcile with one another. Reconciliation restores relationships and opens a 'gateway' to the future. In this way, Moltmann highlighted the theme of the centenary celebration of the Faculty of Theology.

\section{Why is Christ 'the bridge' that crosses the abysses of guilt and the graves of death?}

I myself encountered reconciliation when I was sitting in a prisoner-of-war camp after the Second World War, and felt that I had been forsaken by God and the world. I had been called up in 1944, was stationed at the front in Holland and was taken prisoner in February 1945. The particular event which changed me completely was the first international Student Christian Mission Conference in Swanwick/Derby in the summer of 1947.

A small group of German prisoners of war had been invited and I was one of them. We were still wearing the uniform we had worn during the war. And we came in fear and trembling: What were we to say about the horrors of the war and the mass murders in the concentration camps? But we were welcomed as brothers in Christ and could eat and drink, pray and sing with young Christians who had come from all over the world, even from Australia and New Zealand. We heard no accusations; we didn't feel that we were despised. To be accepted in that way, was a wonderful experience. For the first time I perceived in the Christian faith the great reconciling power which sets standards in the political sphere as well. I resolved to study theology, to become a pastor and to devote my life to this reconciling power of God.

Then a group of young Dutch students came and wanted to talk to us officially. I was nervous about this meeting, because I had been at the front in Holland during the battle for the bridge in Arnheim. The Dutch students told us that the bridge on which they had come to meet us was Christ; without Christ, they would not have exchanged a single word with us and would have had nothing to do with us at all. They told us about the Gestapo terror in their country and about the loss of their Jewish friends, killed by the Germans, and about the destruction of their families. We too could now cross this bridge which Christ had built between them and us, even if only tentatively at first. We could confess the guilt of our people and our own guilt, and beg for forgiveness. For both sides, it was a painful hour of truth. But in the end we embraced. This reconciliation with the Dutch students for me was a liberation. I could breathe again and I felt once more that I was a human being. We returned to our prisoner of war camps with new courage. I no longer felt forsaken by God and the world but rather experienced myself as having been accepted and reconciled. The length of time I still had to remain in captivity, was no longer a matter of concern to me.

In Christ, God was reconciling the world to himself, not counting their trespasses against them and entrusting to us 
the message of reconciliation. So we are ambassadors for Christ, God making his appeal through us: 'We beseech you on behalf of Christ, be reconciled to God' (2 Cor 5:19-20). It is reconciliation that comes to meet us - not wrath, not forsakenness, not chaos. In Christ we perceive the reconciling God. And before God spreads among us (human beings) the word of God's reconciliation, God has already reconciled the world. We have to grasp it: we live in a reconciled world; in spite of cruel wars, in spite of earthquakes and tsunamis, in spite of all the dangers that surround us, this is a reconciled world.

It is not we human beings who reconcile the Deity; it is God who reconciles with himself godless, God-hostile and Godforsaken humanity. By way of their sacrificial cults, from time immemorial, fearful human beings have continually attempted to gain the favour of the gods, in order to turn away their wrath. When there was a famine in the country, when there were floods, it was always 'the others' who had to be sacrificed - the Jews or the early Christians. Fate demands its victims. But in the Christian faith, God is not reconciled by way of human sacrifices; God gives us Christ to reconcile sinners with themselves.

Reconciliation cannot be extorted by force. Reconciliation cannot be bought by way of human sacrifices. We have to pray and beg for reconciliation. God implores us: Let yourselves be reconciled. The crucified Christ with his outstretched arms is the Christ who implores us. In the same way, Christians among human beings are those who implore on God's behalf. It is only in freedom that one can let oneself be reconciled. So, it is the plea, not the threat, which corresponds to reconciliation. We can be afraid of the condemnatory threat, we can close ourselves in response to a quiet, reconciliatory plea, but then we do not experience the liberating power of reconciliation.

How does God bring about reconciliation? By not 'reckoning our sins against us' but by forgiving them. If what comes to meet us out of the mystery of the world is forgiveness, and not punishment, how can we cast up guilt against one another? The person who lives in harmony with God and the world is the person who forgives guilt.

But how can we forgive guilt when our hearts are absorbed by our own hurt?

\section{Excusing oneself}

In German it has become customary to use the phrase 'lch entschuldige mich', - that is to say, 'I excuse myself'. This sentence is the very opposite of a real apology. If I have done someone else an injury, I cannot possibly excuse myself. I have to ask for forgiveness. And for that I have to accuse myself, not excuse myself. Only the people I have wronged can forgive me; in other words, it is only they who can free me from my own guilt. The German self-excuse is the wrong form of excuse, even if German politicians use it to maintain their position. They are then saying: 'But I have excused myself'. That is as much as to say: But I have 'exonerated myself' for the wrong done. What an absurd form of exoneration this self-excuse is!

It is part of a genuine apology to regret and be 'truly sorry' about what one has done to the other person, or has left undone. One feels in oneself the other's pain or hurt, and puts oneself in his or her place. One makes the other person's pain one's own. Through this self-humiliation, one takes upon oneself the humiliation one has caused the other person: 'Es tut mir Leid'. That is, 'It causes me grief'. With the plea for forgiveness, the perpetrator makes the humiliation he has caused the other person his own: with the plea for forgiveness, the perpetrator puts the restoration of his selfrespect into the hands of those who have become the victims of what he has done.

The path into self-humiliation in the face of people I have wronged is difficult, for no one can exist without self-respect. That is why such situations give rise to so much selfjustification and self-pity. Without the confidence that when they are faced by the plea for forgiveness, the victims will cease their reproaches; no perpetrator can admit their guilt. So the victims must open up for the perpetrators who are conscious of their guilt a space of trust in which they divest the guilty of their guilt. It must be preceded not only by the plea for forgiveness but also by the 'removal of guilt', that is, the forgiveness. I am convinced that the preparedness to forgive the wrong must precede the admission of the wrong, if the outcome is to be an unsparing admission of the wrong committed.

\section{The forgiveness of guilt}

The reconciliation of enemies always begins with the forgiveness of guilt. That is the royal right of the victim. For reconciliation, the perpetrators are dependent on the victims. The victims are faced with the question whether they should repay the evil done to them through a similar evil, or whether by way of good they should overcome the evil done to them.

'Do not be overcome by evil, but overcome evil with good', writes the apostle Paul (Rm 12:24). That sounds difficult and somewhat too idealistic. And yet, it is liberating. Everyone who suffers injustice dreams of revenge. That is quite natural: the person who has injured me must suffer the same injury him and/or herself. Then we are quits, and justice has been restored. Whether we call that requital or revenge or justice, the person who repays evil by evil is no better than the perpetrator. The person who murders a murderer is a murderer too. The person who repays evil with evil increases the evil in the world. It is 'the evil which is forced unremittingly to bring forth evil'.

'Do not let yourself be overcome by evil', not even by the evil with which you repay evil. Free yourself from the evil which has entered you with the humiliation. The forgiveness of wrong affects not only the guilty perpetrators, but the victims too. Forgiveness frees them from evil and from the 
perpetrators: It helps the recovery of the victims if they forgive the perpetrators. Forgiveness does not only help the perpetrators to free themselves from the burden of their guilt; it also helps the victims to free themselves from hate, shame and not least from their fixation on the perpetrators.

\section{Delivery from evil}

The forgiveness of guilt means liberation from evil, both for the perpetrators and for the victims. The perpetrator is freed from the guilt that burdens him, and the victim is freed from the evil he has suffered. The perpetrator has to learn to let go of what he has done in the past, and the victim has to let go of his evil recollections. That is only possible if the forgiveness of the guilt is the precondition for a new beginning. If it is only a backward-looking act, forgiveness only brings about the restoration of the state of affairs which led to the evil committed and suffered. Reconciliation is more than the restoration of an earlier state of affairs. It is the beginning of a new future. We see that from the words of 2 Corinthians 5, v. 17, which we already quoted: 'Those who permit themselves to be reconciled with God are, a new creation. The old has passed away, everything has become new'.

The reverse also makes this clear. Without the beginning of a new life, the forgiving and the apology always remain theoretical and artificial. But when the prospect of a different and new life opens up, the forgiving and the letting go become easier. If I have begun something new, it is not difficult to say goodbye to what is old. That is true, first of all, for the victims of the guilt. If they forgive, they let go of what they have suffered and begin a new life. Does that apply to the perpetrators too? I believe that they can more easily confess and admit their guilt if they have the prospect of a new life. How are they to repent if they see no end to the reproaches? How are they to turn back if they know what they are turning back from, but not what they are turning towards?

It is only the new future which makes the past, past. It is only the goodly hope which lays to rest the recollections of evil. It is only the beginning of a new life which allows the tormenting remembrance to be forgotten. When what is new comes, the present becomes old and what is old passes away.

\section{Politics of reconciliation}

Reconciliation is essential for the life of all human relationships. We shall continually incur guilt towards one another, either through the wrong we do to each other or through the good we leave undone. Consequently, to admit and forgive guilt, and thus to create reconciliation, is simply vital for the life we share. Reconciliation is a political matter too. I am speaking as a German about Germany after the Nazi dictatorship and the Second World War, which we began and which was waged in the east with a brutal force that devastated multitudes. I am talking about Germany, 'after Auschwitz', with the focus on the confession of guilt and the plea for forgiveness, reconciliation and the new beginning.
As regards the plea for forgiveness of immeasurable guilt, I always have before my eyes the moment on 07 December 1970 when the German Chancellor Willy Brandt knelt before the memorial to the Jewish ghetto in Warsaw. The German air force already devastated Warsaw by the bombing in 1939 . The Jews were driven into the ghetto and subsequently deported in order then to be murdered in the death camp Treblinka. Warsaw saw the fight to the death in the Jewish ghetto revolt in 1943, commemorated in the ghetto memorial. In 1944 - 1945, Warsaw saw the deadly defeat of the resistance of the Polish national army. It was here that Willy Brandt followed a sudden impulse and knelt down. I remember that my friends and I would have liked to kneel beside him and to ask forgiveness for the burden of guilt of our people, which weighed especially heavily on my generation.

In the Stuttgart Confession of Guilt of the Protestant Church in Germany, our fathers had confessed: 'With great pain we say that through us, endless suffering has been caused to many peoples and countries ... We accuse ourselves'. In 1965, in the Eastern Memorandum of the Protestant Church in Germany, we confessed our guilt towards Poland and begged for reconciliation. In 1966, the Catholic Church followed us. Consequently Willy Brandt's act of penitence became our symbol for reconciliation with the Jews and with the people in Eastern Europe.

The meeting between French President Mitterand and German Chancellor Helmut Kohl on 22 September 1984 on the battlefield of Verdun symbolises reconciliation and a new beginning. The traditional, 'age-old enmity' between Germany and France was ended, and Europe was established. Ever since Napoleon and the German war of liberation of 1813 , there had been enmity between the two nations. German national consciousness was inflated through the victory over France in 1870-71, and intensified through the Battle of Verdun in 1916. The issue here was not the occupation of a little French city. The aim according to the German general staff was to 'bleed the French enemy white'. After 500000 had died, the battle was broken off. There can be no more terrible way of deepening an enmity. In 1945, after the end of the Second World War, in a meeting in Reims cathedral, Charles de Gaulle and Konrad Adenauer strove to arrive at reconciliation. At the same time, the construction of a new Europe began, with the Roman treaties and the coal and steel union. The picture of Mitterand and Kohl hand in hand on the battlefield of Verdun is the picture of a successful reconciliation between two nations and the construction of a trans-national Europe. The two pictures - Willy Brandt kneeling in Warsaw and Mitterand and Kohl hand in hand in Verdun - show that reconciliation can succeed, and how it can do so.

\section{Acknowledgements Competing interests}

The authors declare that they have no financial or personal relationships which may have inappropriately influenced them in writing this article. 


\section{Authors' contributions}

J.B. is the coordinating author; K.N. is the author of the commemoration section; O.F.T. is the author of the tribute to J.M. on behalf of the World Council of Churches; J.M. is the author of the graduation speech at UP and the author of the section on reconciliation.

\section{References}

Bloch, E., 1954/1955/1959, Das Prinzip Hoffnung, 3 vol., R.E. Zimmermann (ed.), De Gruyter, Berlin.

Meadows, D.H., Meadows, D.L., Randers, J. \& Behrens, W.W., III (eds.), 1972, Limits of growth: A report for the Club of Rome's project on the predicament of mankind, Universe Books, New York.
Moltmann, J., [1964] 1967, Theology of hope [Theologie der Hoffnung], transl. M. Kohl, SCM Press, London.

Moltmann, J., [1971] 1973, Theology of joy, transl. R. Ulrich, SCM Press, London.

Moltmann, J., [1972] 1974, The crucified God [Der Gekreuzigde Gott], transl. R.A. Wilson \& J. Bowden, SCM Press, London.

Moltmann, J., 1993, The trinity and human freedom, T \& T Clark, Edinburgh.

Moltmann, J., 2000, Experiences in theology: Ways and forums of Christian Theology [Erfahrungen theologisen Denkens], transl. M. Kohl, SCM Press, London.

Moltmann, J., [2006] 2008, A broad place: An autobiography [Weiter Raum: Eine Lebensgeschicte], transl. M. Kohl, Fortress Press, Minneapolis, MN.

Moltmann, J., 2010, Sun of righteousness, Arise! God's future for humanity and the earth, Fortress Press, Minneapolis, MN.

Moltmann, J., 2012, Ethics of hope [Ethik der Hoffnung], transl. M. Kohl, Fortress Press, Minneapolis, MN.

Moltmann, J., 2015, The living God and the fullness of life [Der lebendige Gott und die Fülle des Lebens], transl. M. Kohl, Westminster John Knox Press, Louisville, KN

Volf, M. \& Crisp, J.E. (eds.), 2015, Joy and human flourishing: Essays on theology, culture and the good life, Fortress Press, Minneapolis, MN. 